\title{
Determination of the main parameters of the photovoltaic solar module
}

\author{
Baydaulet A.Urmashev ${ }^{1}$, Murat Kunelbayev $^{2 *}$, Almas N.Temirbekov ${ }^{3}$, Syrym Kassenov ${ }^{4}$, Zhadra Zhaksylykova ${ }^{5}$, Farida \\ Amenova $^{6}$ \\ ${ }^{1,3}$ Department of Computer Science, Kazakh National University named after al-Farabi, Almaty, Republic of Kazakhstan \\ ${ }^{2}$ Institute Information and Computational Technologies CS MES RK, Almaty, Republic of Kazakhstan \\ ${ }^{4}$ Faculty of Mechanical Mathematics, al-Farabi Kazakh National University, Almaty, Kazakhstan \\ ${ }^{5}$ Abay Kazakh National Pedagogical University, Almaty, Republic of Kazakhstan \\ ${ }^{6}$ S. Amanzholov East Kazakhstan State University, Department of Mathematics, Faculty of Science and Technology \\ Ust-Kamenogorsk, Republic of Kazakhstan
}

\begin{abstract}
This article deals with the determination of the main operating parameters of a photovoltaic solar module. In laboratory tests, the study of the dependence of current, voltage and power on time and density of solar radiation, as well as monitoring of environmental parameters: temperature and humidity of the outside air. Analysis of the test results shows that a photoelectric module with an installed capacity of 800 $\mathrm{W}$ and a total battery capacity of $800 \mathrm{Ah}$ provides the electric power industry with a daily consumption of $2.0 \ldots 2.2 \mathrm{kWh}$. The discharge time of the battery varies from 11.7 to 3.5 hours when the average electric load of the consumer changes from 300 to 1000 watts.
\end{abstract}

\section{Introduction}

Solar cells in the production of electricity from renewable energy sources, is now developing rapidly and soon will be increased overall use [1]. For example, small solar cells used in watches, calculators, small toys, radios and portable TVs. While large objects are combined into modules and are used to supply the power system [2,3]. A solar cell is an electrical device that converts light energy into electricity using the photoelectric effect. The main material used for the production of solar cells is silicon.

II. The design and manufacture of silicon solar battery. Large blocks of molten silicon carefully cooled and solidified is made from cast ingots of polycrystalline silicon square. Polycrystalline silicon is less costly than single crystal and are less effective $[4,3,5]$. Solar battery consists of the following elements $[6,7,8]$.

- $\quad$ Silicon wafer (mono- or polycrystalline) with p$\mathrm{n}$ junctions on the surface.

- Front and back contact; front contact must have the correct shape to make the most of the incident radiation.

- Antireflection layer - cover the front surface. There are three major types of solar cells.

- Single crystal formed on a silicon crystal with a homogeneous structure. The basis for the formation of cells that are suitable silicon-sized blocks.

- They are cut into plates whose thickness is about $0.3 \mathrm{~mm}$. Photovoltaic cells achieve the highest levels of performance and life $[4,6]$.

- $\quad$ Polycrystalline are comprised of many small grains of silicon. These solar cells are less efficient than single crystal. The production process is simpler and have lower rates $[4,6]$.

- Amorphous (thin film) - produced by incorporating multiple layers of silicon on the surface of another material, such as glass. In these solar batteries, we can not distinguish individual cells. Amorphous solar cells are generally used in small devices such as calculators and watches $[4,6,9,10]$. As the metal contacts are made, the solar cells are interconnected by flat wires or metal ribbons, and assembled into modules or solar panels $[7,11,12]$. If the lower flow resistance of the current, the output current is a multiple of the current cell panel and associated with parallel connections of elements and modules. Similarly, the output voltage of the module depends on the amount series-connected cells and modules [3,13]. Photovoltaic solar cell generates electricity only when it is illuminated, electricity is not stored [13].

The current-voltage characteristics of the cell are shown the output current PV generator, depending on the

\footnotetext{
*Corresponding author: murat7508@yandex.kz
} 
voltage at the set temperature and lighting [2.14]. Short circuit current (ISC) - the output current of the photoelectric. Generative at a given temperature and irradiance, PMPP - point MPP (Maximum Power Point) is $[2,6,15]$. The output voltage is heavily dependent on the temperature of solar cells: increase results in a lower operating temperature and efficiency of [2.9]. The paper presents the results of the investigation of the front electrode manufactured using two silver pastes (PV 145 manufactured by $\mathrm{Du}$ Pont and another based on nano powder experimentally prepared) on monocrystalline silicon solar cells in order to reduce contact resistance. The aim of the paper was a comparison between a conventional and an unconventional method to improve the quality of forming electrodes of silicon solar cells [16]. According to the developed method of rational use of solar photo converters, calculations were carried out for a three-phase conversion system for various inversion schemes. According to calculations, it was found that with a three-phase conversion system, it is possible to save from $18.5 \%$ to $35.19 \%$ of expensive solar photo converters [17].

\section{Method}

The laboratory testing program provides for: - study of the dependence of current, voltage and power on time and density of solar radiation; - control of environmental parameters: temperature and humidity of outside air. Studies are conducted in a single-factor method, the experiments are performed in 3-fold replicates.

During the research, the following are recorded: the voltage and current of the FCM, the charging current and the voltage on the batteries, the voltage at the output of the inverter, the temperature of the outside air (from +5 to $+350 \mathrm{C}$ ) and the humidity of the outside air, and the electric power consumption of the electric receivers of the connected load.

In the experimental studies we used: a solar radiation meter SM-206, an ammeter and a DC voltmeter, a UT206 multi meter, a electric energy meter, an CENTER-350 infrared thermometer. The measurement of solar radiation was carried out by a portable device SM-206 with an error of $\pm 5 \%$ (measurement range $0.1 \ldots$ 399.9 W / m2, temperature - infrared thermometer CENTER-350 with an accuracy of $\pm 2 \%$ (measurement range $-20+5000 \mathrm{C})$, temperature and humidity of air were measured by the psychro meter MV-4M with an error of $\pm 4 \%$ and the meteorometer MES-202, the limit of the permissible value of the absolute error of the pressure measurement is not more than $\pm 0,3 \mathrm{kPa}$ in the temperature range from 0 to $600 \mathrm{C}$. Overall dimensions were measured with a tape measure of metal with an error $\pm 0.5 \mathrm{~mm}$ (measuring range 0 to $10 \mathrm{~m}$, the division price is $1 \mathrm{~mm}$ ) and a metal ruler (length $1 \mathrm{~m}$ ) with an error of $\pm 1 \mathrm{~mm}$.

The diagram of connecting devices and equipment during laboratory-field testing is shown in Figure 1.

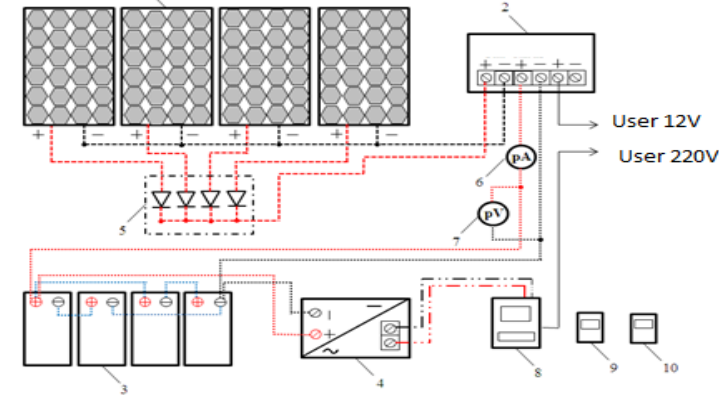

1-photoelectric solar module; 2- controller; 3rechargeable battery; 4- inverter; 5- diodes; 6 - direct current ammeter; 7 - DC voltmeter; 8 - the counter of electric energy; 9 - a solar radiation meter; 10 - a weather meter

Fig.1. Scheme for mounting equipment and connecting devices

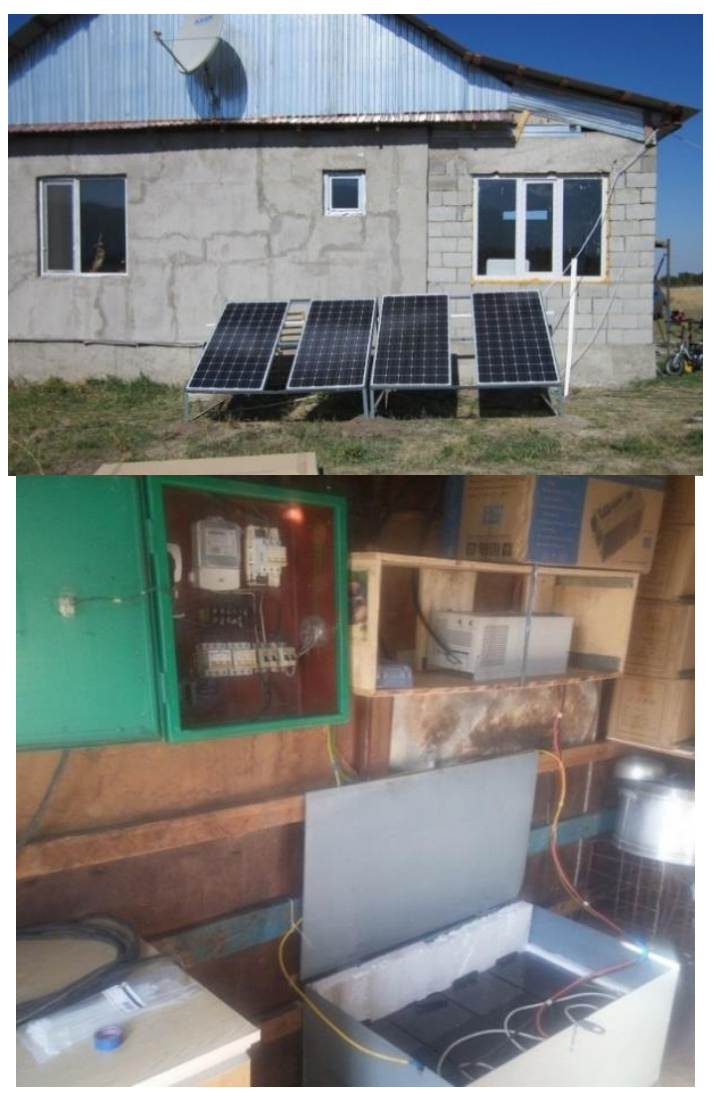

Fig.2.General view of the prototype of the photovoltaic solar module 


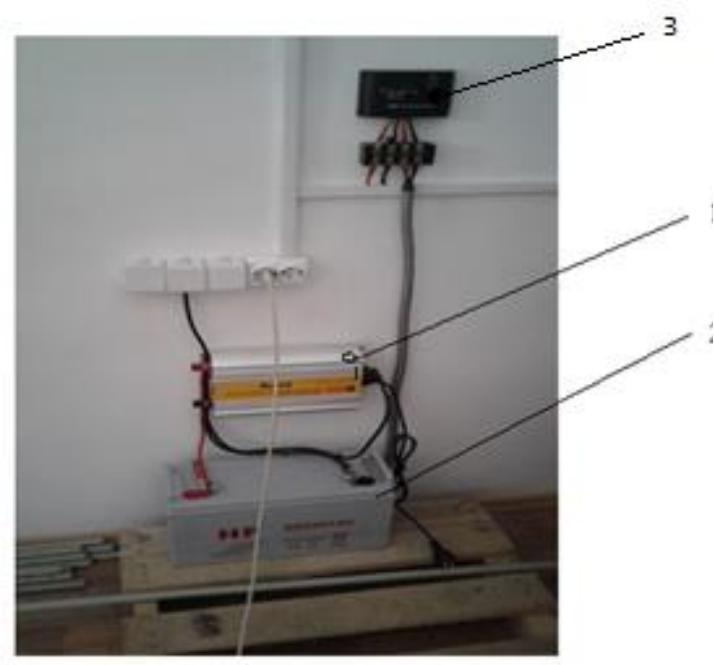

1- inverter; 2- battery;3-controller

Fig.3. The solar power systems

\section{Inverter to convert $D C$ to $A C$ voltage}

The objective of this study is to reduce the load on the power supply with maximum efficiency and increase the term of stability, simplify the design of the device, reduce the cost and expand the scope of their use in industry. This task is achieved by the fact that when turning on the PWM controller that regulates the width of the pulses 1 to the logic elements 3, 4, the maximum sequence of gates of field-effect transistors is achieved.

As shown in Figure 1, the device has a PWM controller that regulates pulse width 1 , voltage regulator 2 , with field-effect transistors connected 3.4, to convert from DC to $\mathrm{AC}$, capacitors 5, to filter the input voltage, diode bridge 6, transformer consisting of primary and secondary windings 7 , switch 8 , housing 9 , you can use any material, plastic, iron, aluminum.

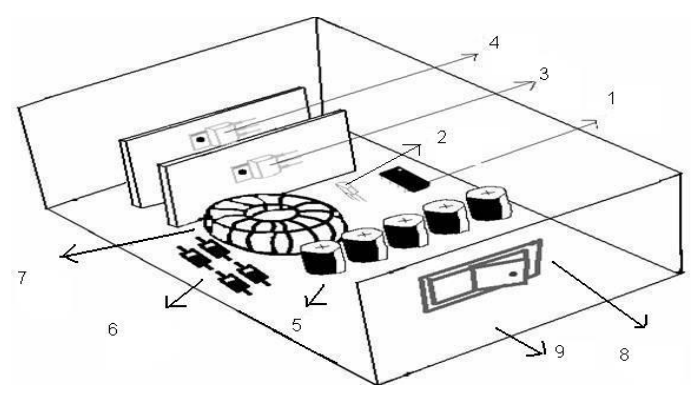

Fig.4. Inverter to convert DC voltage to AC

Assembly and manufacture of the device is as follows. A PWM controller regulating pulse width 1 is connected via voltage regulator 2 , and capacitors 5 , for filtering and limiting the input voltage, followed by connecting fieldeffect transistors 3, 4, screwed to passive cooling, to prevent heating, and with parallel connection of the secondary winding transformer 7 , the primary winding is connected directly to the diode bridge 6 , with the connection to the input voltage circuit of the switch 8 , with the subsequent location in the housing 9.

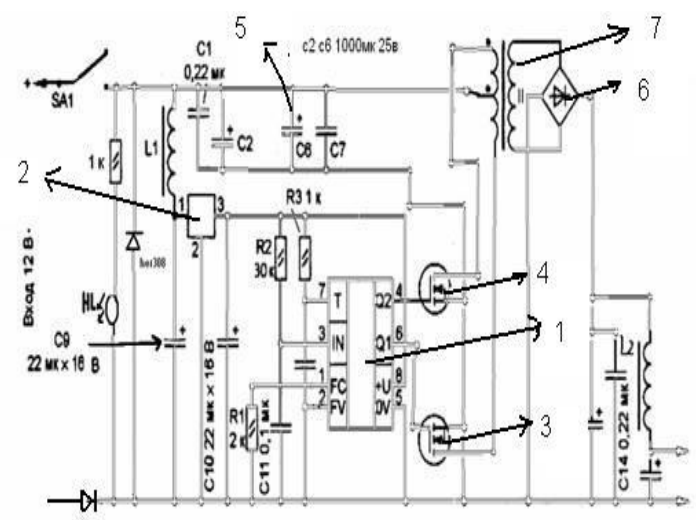

Fig.5. Schematic diagram of the inverter

The operation of the proposed device is as follows. When the input voltage is connected, with the switch 8 connected to the input voltage circuit, the current is fed to the PWM controller that controls the pulse width 1 , through the capacitors 5 , to filter the current, and the voltage regulator 2 , then connect the field-effect transistors 3, 4 screwed to the passive cooling, to prevent heating, and with the parallel connection of the secondary winding of the transformer 7 , the primary winding is connected directly to the diode bridge 6 , with the connection to the input voltage circuit of the switch 8 , followed by $\mathrm{p}$ As position in the housing 9 .

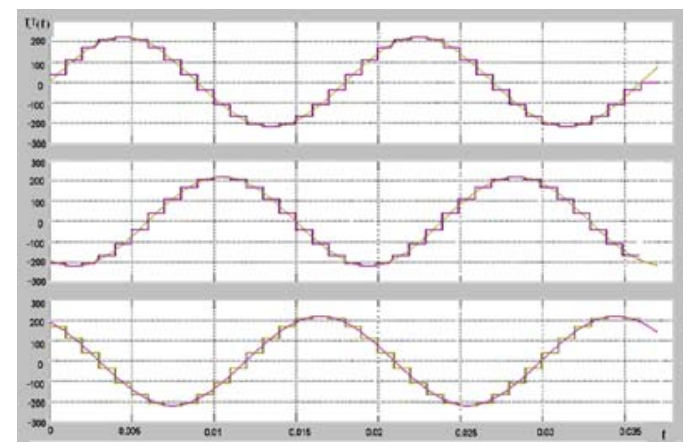

1- Output step voltage curve; 2 - perfect sine curve

Fig.6. The output voltage of a three-phase five-step model

In accordance with the graphical analysis, it can be asserted that with a three-phase load, as the steps grow, a voltage curve can be obtained that is close to a sinusoid.

\section{Experimental investigation}

The study of the dependence of the hourly generation of electricity on the state of cloudiness showed that for a clear sky it was $1520 \mathrm{Wh}$, with an average clouds of 831 $\mathrm{Wh}$, and with a strong cloud cover of $302 \mathrm{~W} / \mathrm{h}$ (Figure 
7).

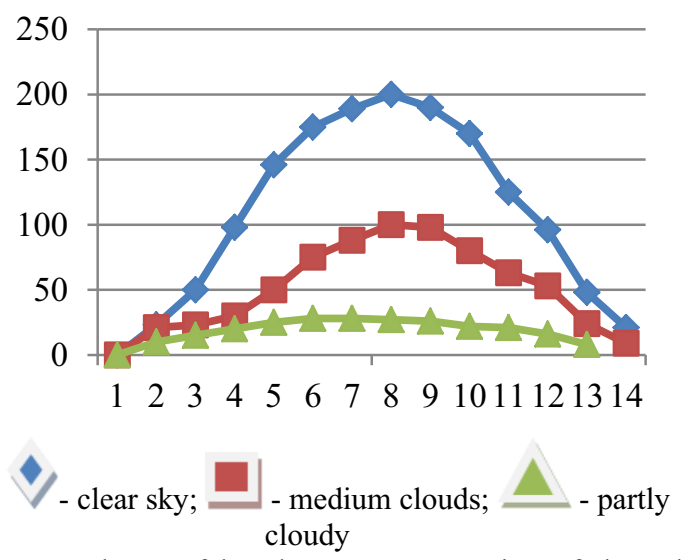

Fig. 7. Dependence of hourly power generation of the solar module on the state of cloudiness (July, installed power $200 \mathrm{~W}$ )

An analysis of the data of the hourly power generation of the solar module shows that: - with a clear sky (total solar radiation per day $9675 \mathrm{~W} \cdot \mathrm{h} / \mathrm{m} 2$ ), electricity generation was $1520 \mathrm{Wh} \cdot \mathrm{h}$; - at an average cloud cover (total solar radiation per day $5295 \mathrm{~W} \cdot \mathrm{h} / \mathrm{m} 2$ ), the generation of electricity was $831 \mathrm{Wh} \cdot \mathrm{h}$; - with a strong cloud cover (total solar radiation for the day of 1920 $\mathrm{W} \cdot \mathrm{h} / \mathrm{m} 2$ ), the generation of electricity was $302 \mathrm{Wh} \cdot \mathrm{h}$. A study of solar module operation in the mode of orientation to the sun showed that in this case, daytime power generation increases by $52 \%$ from $596 \mathrm{Wh}$ to 888 $\mathrm{W} \cdot \mathrm{h}$ (for July conditions) as compared to the fixed installation of solar panels with a south orientation Figure 7).

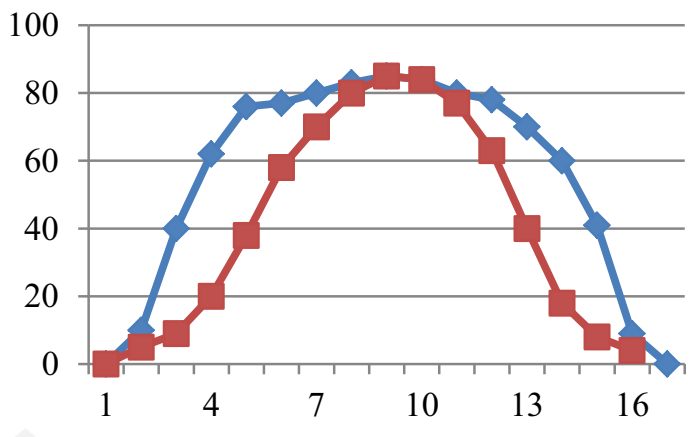

- in the mode of tracking the sun; $[$ - constant orientation to the South

Fig.8. Change in solar module power during the day in the mode of tracking the sun with average clouds (July)

The change in the intensity of solar radiation during a light day during laboratory-field testing is shown in Figure 8 .

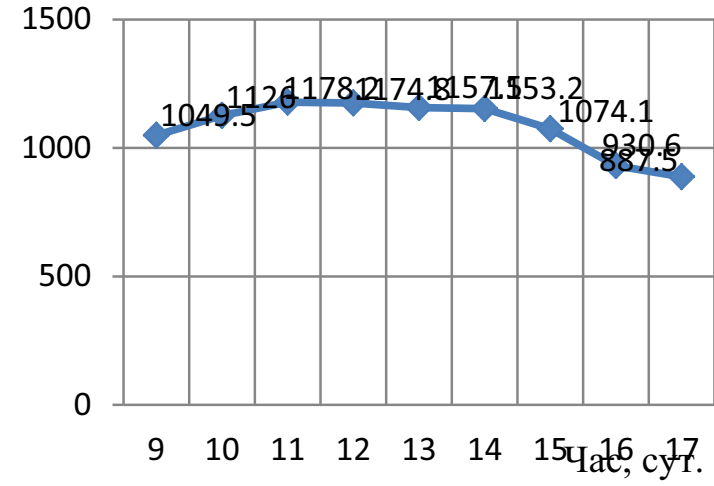

Fig. 9. Change in the intensity of solar radiation during a light day with a clear sky (September, total solar radiation per unit area per day is $9.71 \mathrm{kWh} / \mathrm{m}^{2}$ )

According to the graph in Fig.9, the total solar radiation per day for photovoltaic modules with a total area of $4.8 \mathrm{~m} 2$ is $46.6 \mathrm{kWh}$, therefore, taking into account the average efficiency of $14 \%$, the average amount of electricity produced per day is $6,53 \mathrm{kWh}$. Summary indicators of laboratory-field tests are given in Table1, and the characteristics of the test conditions in Table 2 .

Table 1. Summary of test scores

\begin{tabular}{|l|l|l|}
\hline Indicator name & $\begin{array}{l}\text { unit } \\
\text { of } \\
\text { meas } \\
\text { urem } \\
\text { ent }\end{array}$ & $\begin{array}{l}\text { Indicator } \\
\text { value }\end{array}$ \\
\hline Performance of the solar module \\
\hline - - peak power & Watt & 175 \\
\hline - average power & Watt & 116,8 \\
\hline $\begin{array}{l}\text { - open circuit } \\
\text { voltage }\end{array}$ & V & $38 \ldots 44$ \\
\hline $\begin{array}{l}\text { - stress under } \\
\text { load }\end{array}$ & V & $24 \ldots 26,4$ \\
\hline - load current & A & $6,2 \ldots 11,5$ \\
\hline Battery Performance \\
\hline - capacity & A·h & $93,5 \ldots 103,5$ \\
\hline - charge current & A & $6,2 \ldots 11,5$ \\
\hline - voltage & V & $24 \ldots 26,4$ \\
\hline - charge time & h & $9 \ldots 11$ \\
\hline Inverter performance \\
\hline - input voltage & V & $24 \ldots 26,4$ \\
\hline - output voltage & V & 220 \\
\hline $\begin{array}{l}\text { - input load } \\
\text { current }\end{array}$ & A & 44,8 \\
\hline - output current & A & 5,45 \\
\hline \multicolumn{2}{|l}{} \\
\hline
\end{tabular}


Table 2. Characterization of test conditions

\begin{tabular}{|l|l|l|}
\hline $\begin{array}{l}\text { Indicator } \\
\text { name }\end{array}$ & $\begin{array}{l}\text { unit of } \\
\text { measurement }\end{array}$ & Indicator value \\
\hline \multicolumn{3}{|c|}{ Characteristics of climatic conditions } \\
\hline $\begin{array}{l}\text { outside } \\
\text { temperature }\end{array}$ & ${ }^{0} \mathrm{C}$ & $23 \ldots 30$ \\
\hline $\begin{array}{l}\text { relative } \\
\text { humidity of } \\
\text { outside air }\end{array}$ & $\%$ & $72 \ldots 90$ \\
\hline $\begin{array}{l}\text { intensity of } \\
\text { solar } \\
\text { radiation }\end{array}$ & Watt $/ \mathrm{m}^{2}$ & $887,5 \ldots 1178,2$ \\
\hline
\end{tabular}

\section{Result}

Analysis of the test results shows that the solar module with an installed capacity of $800 \mathrm{~W}$ and a total capacity of 800 Ah batteries provides the company with electricity with a daily consumption of $2.0 \ldots 2.2 \mathrm{kWh}$. The discharge time of the battery varies from 11.7 to 3.5 hours when the average electric load of the consumer changes from 300 to 1000 Watts. Figure 6 shows the annual electricity production schedule, calculated from the average monthly solar radiation intensity. These graphs show that the annual integrated power generation of a solar module with an installed capacity of $200 \mathrm{~W}$ is $184.4 \mathrm{kWh} /$ year, with an efficiency of about $14 \%$ for this type of solar module, based on single-crystal silicon sheets (first-generation photocells). As can be seen from the graph, the greatest value of solar radiation falls on the period from April to October.

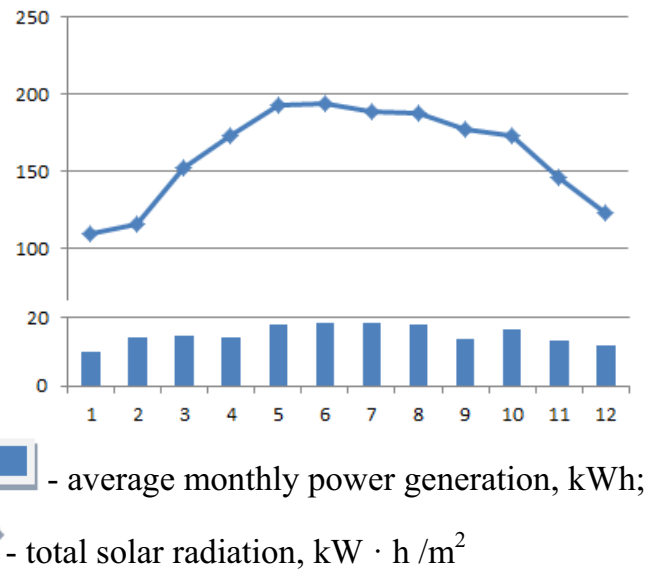

Fig.10. The annual schedule of power generation of a solar module with an installed capacity of $200 \mathrm{~W}$

Thus, for the solar module, the estimated annual power generation is $737.6 \mathrm{kWh}$, therefore, the daily output is $2.02 \mathrm{kWh}$.

\section{Conclusion}

The photovoltaic solar module with an installed capacity of 800 watts provides the electric power with a daily consumption of $2.0 \ldots 2.2 \mathrm{kWh}$, the discharge time of the battery varies from 11.7 to 3.5 hours when the average electric load of the consumer changes from 300 to 1000 Tues. The annual integrated power generation of a solar module with an installed capacity of 200 Watt is 184.4 $\mathrm{kWh} /$ year, with an efficiency of about $14 \%$ for this type of modules based on single-crystal silicon sheets (firstgeneration photocells). As can be seen from the experiment, the greatest value of solar radiation falls on the period from April to October.

\section{Reference}

1. Fundamentals of Photovoltaics: http://www.fotowoltaika.com.pl/podstawy.htm

2. E. Klugmann-Radziemska, Photovoltaic, in theory and practice, Publishing House BTC, Legionowo, (2010) (in Polish).

3. Photovoltaicshttp://www.acce.apsl.edu.pl/instrukcje/ fotoogniwo_ogniwo\%20sloneczne.pdf (in Polish).

4. F. Wolanczyk, How to use the power of gifts, the solar collectors and photovoltaic cells, Publishing House KaBe, Krosno, (2011) (in Polish)

5. M. Lipinski, Silicon nitride for photovoltaic application, Archives of Materials Science and Engineering 46/2 (2010)

6. T. Rodacki, A. Kandyba, Energy conversion in solar power, Wydaw. Politechniki Slaskiej, Gliwice, (2000) (in Polish).

7. L.A. Dobrzanski, M. Szindler, Sol-gel and ALD antireflection coatings for silicon solar cells, Electronics: structures, technologies, applications 53/8 (2012)

8. T. Markvart, L. Castaner, Practical handbook of photovoltaics, fundamentals and applications, Oxford, Elsevier, (2006)

9. Thin film solar cell http://www.labfiz2p.if.pw.edu.pl/ ins/cos_nr_9.pdf (in Polish).

10. R. Brende, 1 Thin-film crystalline silicon solar cells, physics and technology, Wiley-VCH, Weinheim, (2003)

11. P. Würfel, Physics of solar cells: from basic principles to advanced concepts, Wiley-VCH Verlag, Weinheim,(2009)

12. L.A. Dobrzanski, M. Musztyfaga, Effect of the front electrode metallisation process on electrical parameters of a silicon solar cell, Journal of Achievements in Materials and Manufacturing Engineering 48/2 (2011)

13. M. Waclawek, T. Rodziewicz, Solar cells: the impact of the environment on their work, Publishing House WNT, Warsaw, (2011) (in Polish)

14. H.J. Moller, Photovoltaics - current status and perspectives, Environment Protection Engineering 32/1 (2006)

15. L.A. Dobrzanski, M. Musztyfaga, Effect of the front electrode metallisation process on electrical parameters of a silicon solar cell, Journal of 
Achievements in Materials and Manufacturing Engineering 48 /2 (2011)

16. L.A. Dobrzanski, M. Musztyfaga, A. Drygala, Final manufacturing process of front side metallisation on silicon solar cells using convectional and unconventional techniques, Journal of Mechanical Engineering 59 (2013)
17. M. Kalimoldayev, M. Akhmetzhanov, M. Kunelbayev. Development And Research Of A Mathematical Model Of A Solar Photo Converter With An Inverter For Converting Direct Current To Alternating Voltage. N E W S Of The National Academy Of Sciences Of The Republic Of Kazakhstan Physico-Mathematical Series. Volume 4, Number 326 (2019) 